\title{
Overdesign of Villa Structures in Oman
}

\author{
A.S. Alnuaimi*a, M. Al Mohsin ${ }^{\text {b }}$, A. Hagoc and S. El Gamald \\ a,c,d Department of Civil and Architectural Engineering, College of Engineering, Sultan Qaboos University, Oman. \\ ${ }^{b}$ Department of Civil and Architectural Engineering, College of Engineering, University of Buraimi, Oman.
}

Received 24 March 2015; Accepted 15 July 2015

\begin{abstract}
Residential projects represent the largest section of the construction industry in Oman. It is widely claimed that designers in Oman tend to unnecessarily overdesign structures, thereby aggravating construction costs. The aim of this research was to investigate the existence and extent of structural overdesign through the investigation of 31 villas which were approved by Muscat Municipality between 2000-2010. The specified villas were structurally redesigned based on the British Code of Practice using the same geometry and material strengths recorded in the drawings. The required reinforcement resulting from the redesign work was compared with the provided reinforcement as per the drawings. The results showed clear cases of extra reinforcement in almost all villas. The difference between required and provided reinforcements in the villas ranged from 2.3$104.8 \%$, with an average of $48.5 \%$ and a standard deviation of 24.0 . The required and provided weights of reinforcement per square meter of the built-up area ranged from $25.7-71$ and $40.9-87.9 \mathrm{~kg} / \mathrm{m}^{2}$, respectively. The largest differences between the required and provided reinforcement were in the slabs, followed by the footings. A field survey of consultants and municipality engineers indicated that the most notable reasons for overdesign are the absence of authorized agents specialized in reviewing structural design, a lack of an engineering licensing system in Oman, and the phenomenon of experienced engineers leaving design offices for better paying jobs elsewhere. Finally, the cost implication of overdesign is minor compared to the overall cost of building.
\end{abstract}

Keywords: Villa design, Structural design, Oman, Municipality design approval.

$$
\begin{aligned}
& \text { الإفراط بِّ تصميم منشآت الفلل ِِّ سلطنة عمان } \\
& \text { علي سعيد النعيمي، محمد المحسن، عبد الواحد هجو، وشريف الجمال }
\end{aligned}
$$

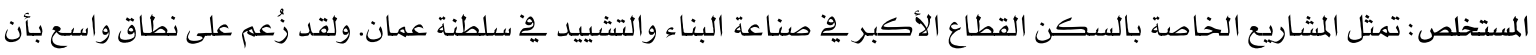

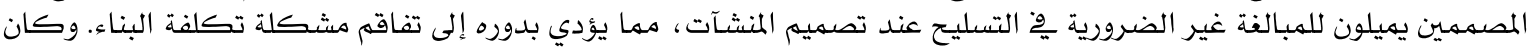

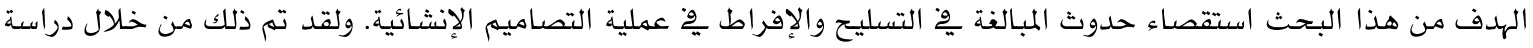

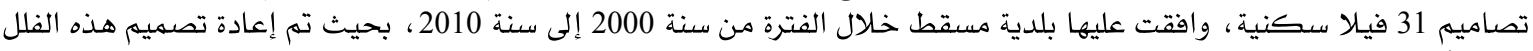

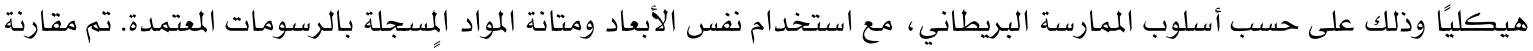

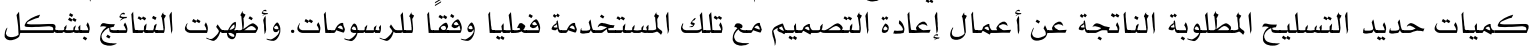

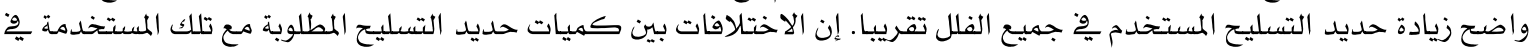

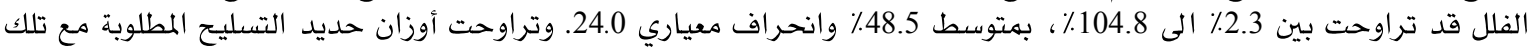

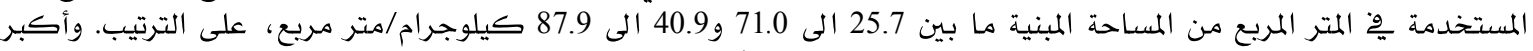

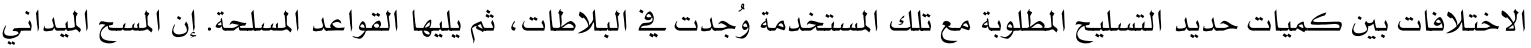

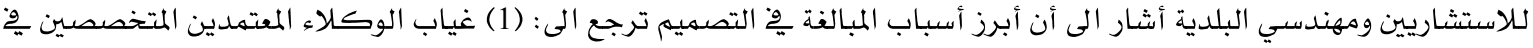

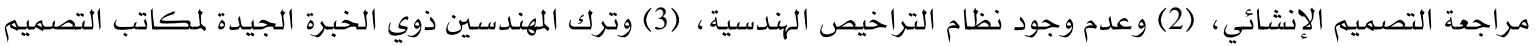

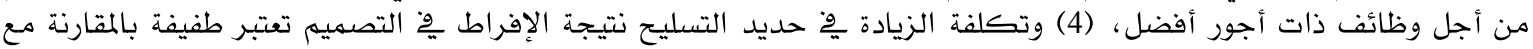
التكلفة الإجمالية للبناء.

$$
\text { الكلمات المفتاحية : تصميم الفلل، التصميم الإنشائي، عمان، اعتماد تصميم البلدية. }
$$




\section{Introduction}

With cost escalation in building construction, owners seek ways of reducing both the cost and time spent on providing decent residential buildings. Designers should be responsible for providing a safe and cost-effective building to suit their clients' needs. However, the objectives of maximizing the degree of technical performance and safety while minimizing cost are usually in conflict. Every design code explicitly stipulates certain safety factors that have been determined to be adequate for loads and material strengths. Overdesigning, or creating a building that goes beyond these limits, is a waste of resources as it provides unjustified levels of safety.

A small number of researchers have examined overdesign practices occurring in the Gulf Cooperative Council (GCC) countries. Sadek et al. (2006) used American Concrete Institute (ACI) provisions for the structural redesign of six typical villas in Kuwait and stated that due to the absence of a unified national building code, largex variation in the quality of design practices exercised by private consultants confirms the nonuniformity of designs and structural overdesign of residential units when compared to ACI codes. They found the average percentage of extra reinforcement to be $30 \%$ for slabs and $60 \%$ for beams and columns. Columns were substantially oversized in terms of concrete dimensions as the carrying capacity of these elements as per the existing design was found to be higher than the actual applied loads by as much as $240 \%$ on average. The concrete material, steel strength, soil bearing capacity, and structure dimensions were maintained as per the existing design, keeping the reinforcement ratio as the only variable.
Arafah et al. (1999) studied problems related to reinforced concrete buildings due to the absence of a unified national code in Saudi Arabia, starting from the high cost of maintenance to complete structural collapse. They emphasized the need for a unified structural design code in Saudi Arabia to avoid discrepancies in design, maintain quality, and assure safety and serviceability. AlNegheimish et al. (2002) studied the design of 41 residential buildings in Riyadh, Saudi Arabia, to evaluate the design practices in the district's small design offices. They concluded that gross and wasteful simplifications were common practice and emphasized the urgent need for a national code of practice for design and quality control. No information was found in the literature about the design practice for villas in Oman; Sadek et al. (2006) seem to be the only researchers investigating the presence and extent of overdesign in the GCC.

Residential projects represent the largest section of the construction industry in Oman; Ministry of Economy (2011). Table 1 shows the annual number of building permits issued during the period 20002010 in Muscat; (Muscat Municipality (2011)), which is home to $40 \%$ of Oman's population of approximately 3.6 million. With this statistic in mind, the objectives of this study are to investigate the existence and extent of overdesigned villa structures in Muscat, study the effect of such design on the total weight of reinforcement, determine the causes of overdesign in Muscat's villas, and propose solutions to the issue of overdesign. The significance of this study originates from the fact that it investigates the appropriateness of the design of villa-type housing, which is the most popular kind of accommodation in Oman and the GCC.

Table 1. Number of building permits issued during the period from 2000 to 2010 in Muscat.

\begin{tabular}{ccccccc}
\hline $\begin{array}{c}\text { Loar } \\
\text { Yeation }\end{array}$ & Mutrah & Al-Amerat & Al-Seeb & Baushar & Qurayat & Total \\
\hline 2000 & 118 & 96 & 715 & 456 & 90 & 1475 \\
2001 & 110 & 136 & 835 & 436 & 72 & 1589 \\
2002 & 131 & 197 & 1060 & 574 & 88 & 2050 \\
2003 & 147 & 247 & 1169 & 565 & 110 & 2238 \\
2004 & 118 & 247 & 894 & 545 & 115 & 1899 \\
2005 & 124 & 333 & 924 & 553 & 127 & 2061 \\
2006 & 142 & 430 & 1081 & 558 & 129 & 2340 \\
2007 & 146 & 469 & 1234 & 574 & 142 & 2565 \\
2008 & 196 & 812 & 2251 & 809 & 226 & 4294 \\
2009 & 215 & 807 & 2228 & 767 & 198 & 4215 \\
2010 & 224 & 869 & 2015 & 663 & 200 & 3971 \\
\hline \multicolumn{7}{c}{ Total (2000-2010) } \\
\hline
\end{tabular}




\section{Scope of Work and Methodology}

The study data gathered from Muscat Municipality was comprised of drawings of 31 villas approved for construction in various locations around Muscat from 2000-2010. The drawings included architectural, structural, plumbing, electrical, and material information for construction purposes. The villas had been designed by different small to medium-size consultancy offices and lacked signs of the firms have used design software or a named code of practice. Because the British code is widely used for structural design in Oman, the villas were redesigned as part of this research using British code British Standard (BS) 8110:97 (1997). A detailed structural analysis of all the villas was performed to find the bending moments, shear forces, and reactions of the supports using STAAD.Pro structural analysis and design engineering software (2007) (Bentley Systems, Inc., Exton, Pennsylvania, USA). The redesign followed BS8110 using Reinforced Concrete Council (RCC) spread sheets (2012) for the design of slabs and footings and STAAD.Pro for the design of beams and columns. The materials' characteristic strengths and soil bearing capacity were kept as specified in the approved drawings, and the dimensions of the structural elements, geometry of the building and locations of footings were also maintained according to specifications. The weight of the materials and the dead load were calculated based on the type and thickness of finishes specified in the drawings. Live loads were selected based on the BS6399-Part 1 (1996) code requirements for different uses. The concrete density was $24 \mathrm{kN} / \mathrm{m}^{3}$ and the characteristic yield strength of the longitudinal and transverse reinforcement was $460 \mathrm{MPa}$. The concrete cover for reinforcement was also kept as directed in the approved drawings. The factors of safety for dead and live loads were 1.4 and 1.6, respectively. The only variable was the amount of reinforcement. Random design checks were carried out for some elements using both manual calculations and based on the BS8110:97 code to ensure correctness of results. Our use of the term "provided" refers to the amount of reinforcement provided in the drawings approved by the Muscat municipality, while the term "required" represents the amount of reinforcement required, based on the redesign carried out as part of this research. The provided and required amounts of reinforcement for all structural elements forming the skeleton were compared. All the reinforced concrete slabs were either one-way or two-way with thicknesses ranging from $120-200 \mathrm{~mm}$. All the beams were reinforced concrete plinth, downstand, and hidden beams. The width of the plinth beams was $200 \mathrm{~mm}$ and their depth ranged from $300-700 \mathrm{~mm}$. The width of the downstand beams ranged from 200$400 \mathrm{~mm}$ with a depth ranging from $320-900 \mathrm{~mm}$. The width of the hidden beams ranged from 300$1400 \mathrm{~mm}$ and their depth was from $240-420 \mathrm{~mm}$. Most of the columns used in the selected villas were rectangular. There were also some circular columns, mainly in the open halls. The rectangular dimensions varied from $200-1200 \mathrm{~mm}$ and the circular columns' diameters ranged from 200-300 $\mathrm{mm}$. All footings were pad or combined with lengths ranging from 0.9-3.4 m, widths ranging from $0.9-3 \mathrm{~m}$, and thicknesses ranging from 0.3$0.75 \mathrm{~m}$. The length of the combined footings ranged from 1.6-6.4 $\mathrm{m}$, the width ranged from 1.2$3.8 \mathrm{~m}$, and the thickness ranged from $0.3-0.75 \mathrm{~m}$. The RCC spreadsheets were used to calculate the required reinforcement for the footings and slabs, while the STAAD.Pro program was used for the design of the columns and beams.

\section{Results}

The required reinforcement that resulted from the redesign of the 31 villas was compared with the provided reinforcement given in the approved drawings. The percentage of difference between the provided and required reinforcement was calculated as

$$
\text { (provided - required)/required) x 100) }
$$

The characteristic concrete strength used ranged between $25-35 \mathrm{~N} / \mathrm{mm}^{2}$, and the soil bearing capacity ranged from $150-250 \mathrm{kN} / \mathrm{m}^{2}$. The concrete cover to reinforcement of slabs and beams was between $25-30 \mathrm{~mm}$, while for columns it was between $30-40 \mathrm{~mm}$, and $50 \mathrm{~mm}$ for the footings. The comparison relates to individual elements and the total required and provided reinforcements for the whole villa.

\subsection{Slabs}

Figure 1 shows the total required and provided reinforcements for each villa and makes clear that almost all the slabs were provided with more reinforcement than required. The total required and provided reinforcement for the slabs of the 31 villas were 159.9 tons and 273.1 tons, respectively. The percentage of difference ranged from -2.8- 
$162.0 \%$, with an average of $75.6 \%$ and a standard deviation (SD) of 42.8 .

\subsection{Beams}

Figure 2 shows the required and provided beam reinforcements. It can easily be seen that all beams have more reinforcement than required. The total required and provided reinforcement for the beams of the 31 villas were 269.8 tons and 387.3 tons, respectively. The percentage of difference ranged from $0-102.91 \%$ with an average of $44.2 \%$ and a SD of 32.0 .

\subsection{Columns}

Figure 3 shows the required and provided reinforcements of columns. With the exception of one villa (V26), all the columns were provided with more reinforcement than required. The total required and provided reinforcement for the columns of the 31 villas were 180.5 tons and 246.63 tons, respectively. The percentage of difference ranged from $-13.3-78.3 \%$, with an average of $37.4 \%$ and a SD of 24.0. There were some cases of underdesign.

\subsection{Footings}

Figure 4 shows the required and provided reinforcements of footings. Apart from one villa (V30), all the footings were provided with more reinforcement than required. The total required and provided reinforcement for the footings of the 31 villas were 114.6 tons and 169.0 tons, respectively. The percentage of difference ranged from $0-182.4 \%$, with an average of $57.6 \%$ and a SD of 45.1 .

\subsection{Total Reinforcement}

Figure 5 shows the total required and provided reinforcements for all the villas; all were provided

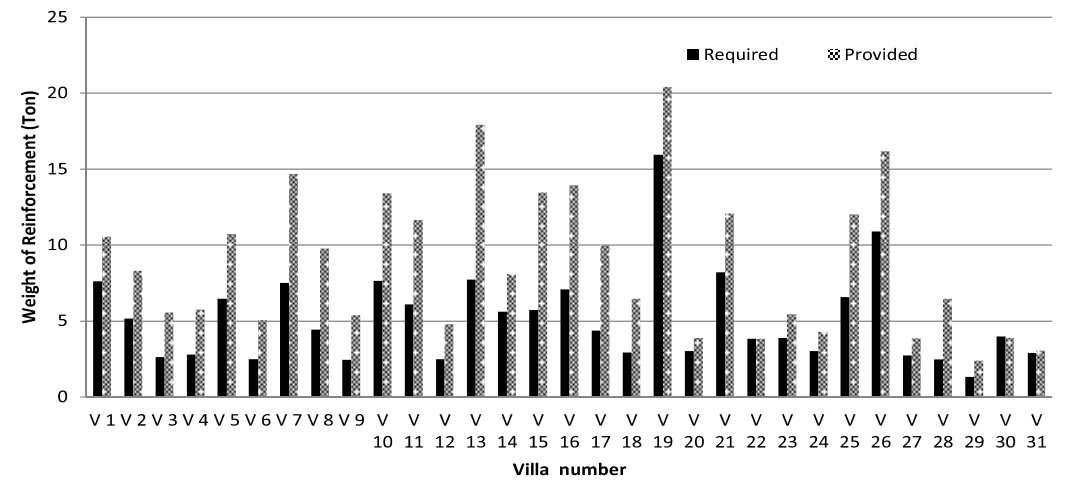

Figure 1. Required and provided slabs' reinforcements for all villas.

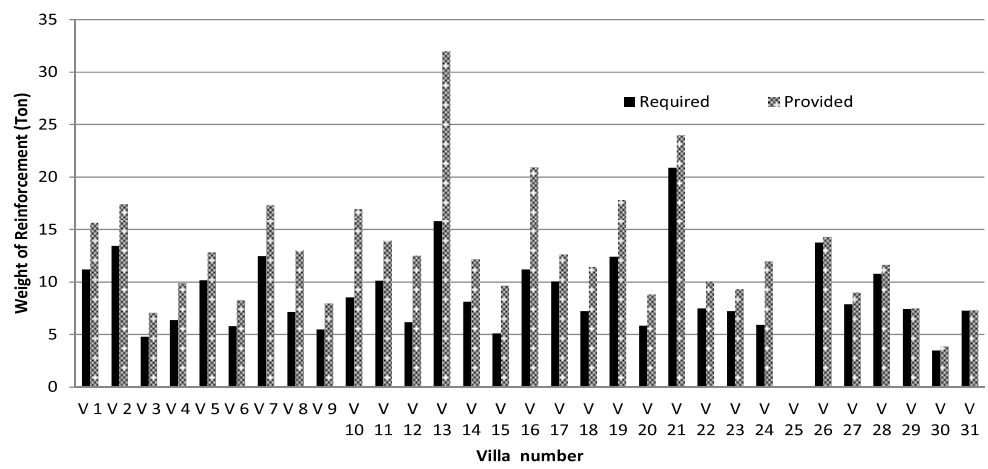

Figure 2. Required and provided beams' reinforcements for all villas. 


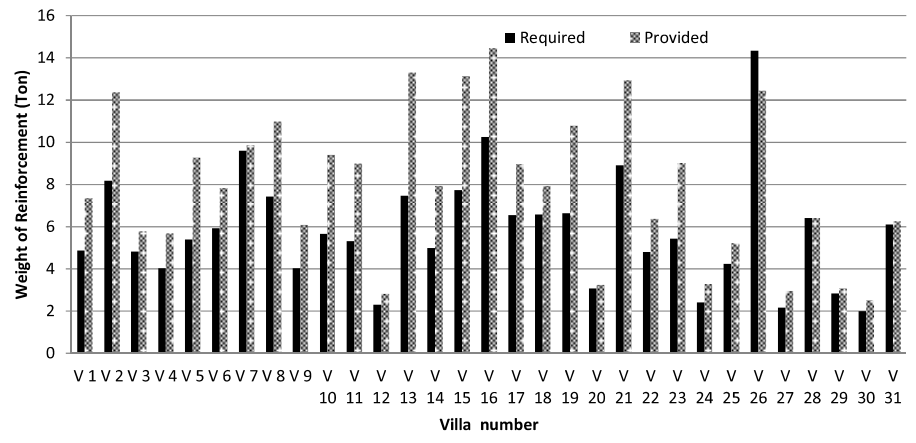

Figure 3. Required and provided columns' reinforcements for all villas.

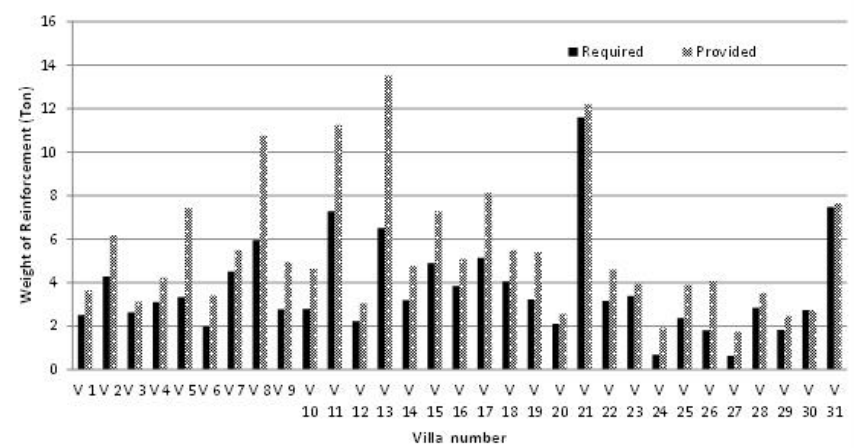

Figure 4. Required and provided footings' reinforcements for all villas.

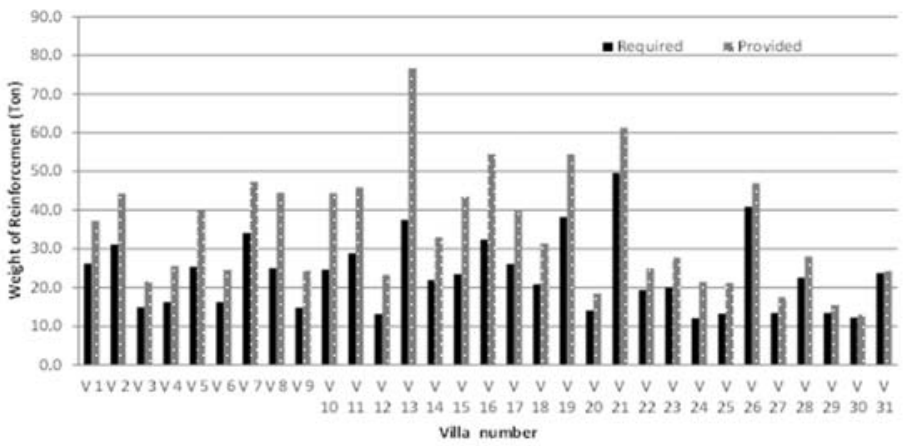

Figure 5. Comparison between total required and total provided reinforcement in all villas. 
Table 2. Ratios of total amount of reinforcement to built-up area.

\begin{tabular}{|c|c|c|c|c|c|}
\hline $\begin{array}{l}\text { Villa } \\
\text { No. }\end{array}$ & $\begin{array}{l}\text { Number } \\
\text { of floors }\end{array}$ & $\begin{array}{l}\text { Total built } \\
\text { up area }\left(\mathrm{m}^{2}\right)\end{array}$ & $\begin{array}{c}\text { Ratio of } \\
\text { required } \\
\text { reinforcement } \\
\left(\mathrm{kg} / \mathrm{m}^{2}\right)\end{array}$ & $\begin{array}{c}\text { Ratio of } \\
\text { provided } \\
\text { reinforcement } \\
\left(\mathrm{kg} / \mathrm{m}^{2}\right) \\
\end{array}$ & \% Dif. \\
\hline V1 & 2 & 631.86 & 41.46 & 58.84 & 41.91 \\
\hline V 2 & 3 & 911.40 & 34.08 & 48.56 & 42.50 \\
\hline V 3 & 2 & 334.56 & 44.42 & 64.38 & 44.95 \\
\hline V 4 & 2 & 367.96 & 44.24 & 69.36 & 56.76 \\
\hline V 5 & 3 & 623.10 & 40.70 & 64.58 & 58.68 \\
\hline V 6 & 2 & 392 & 41.38 & 62.60 & 51.29 \\
\hline V 7 & 3 & 1036.8 & 32.89 & 45.66 & 38.83 \\
\hline V 8 & 2 & 626.24 & 39.86 & 71.12 & 78.45 \\
\hline V 9 & 2 & 350.68 & 42.03 & 69.41 & 65.13 \\
\hline V 10 & 3 & 707.40 & 34.80 & 62.77 & 80.34 \\
\hline V 11 & 3 & 1122.00 & 25.69 & 40.86 & 59.06 \\
\hline V 12 & 2 & 353.72 & 37.26 & 65.59 & 76.02 \\
\hline V 13 & 3 & 1078.35 & 34.74 & 71.15 & 104.81 \\
\hline V 14 & 3 & 630.00 & 34.76 & 52.29 & 50.41 \\
\hline V 15 & 3 & 697.89 & 33.56 & 62.39 & 85.91 \\
\hline V 16 & 3 & 810 & 40.00 & 67.16 & 67.90 \\
\hline V 17 & 3 & 725.16 & 35.99 & 54.77 & 52.18 \\
\hline V 18 & 3 & 597.6 & 34.77 & 52.51 & 51.01 \\
\hline V 19 & 2 & 719.94 & 53.06 & 75.56 & 42.41 \\
\hline V 20 & 2 & 225 & 62.49 & 82.13 & 31.44 \\
\hline V 21 & 3 & 698.72 & 70.96 & 87.59 & 23.44 \\
\hline V 22 & 2 & 430.00 & 44.84 & 57.72 & 28.73 \\
\hline V 23 & 2 & 447.40 & 44.48 & 62.00 & 39.40 \\
\hline V 24 & 2 & 285.84 & 42.12 & 74.94 & 77.91 \\
\hline V 25 & 2 & 305.38 & 43.34 & 69.37 & 60.07 \\
\hline V 26 & 3 & 846.45 & 48.18 & 55.49 & 15.16 \\
\hline V 27 & 2 & 298.33 & 44.95 & 58.74 & 30.69 \\
\hline V 28 & 2 & 476.65 & 47.17 & 58.75 & 24.54 \\
\hline V 29 & 2 & 300.60 & 44.61 & 51.20 & 14.77 \\
\hline V 30 & 2 & 290.17 & 42.05 & 44.76 & 6.46 \\
\hline V 31 & 3 & 525.89 & 45.09 & 46.12 & 2.30 \\
\hline \multicolumn{3}{|c|}{ Average $\left(\mathrm{kg} / \mathrm{m}^{2}\right)$} & 42.13 & 61.56 & 48.50 \\
\hline \multicolumn{3}{|c|}{$\operatorname{Min}\left(\mathrm{kg} / \mathrm{m}^{2}\right)$} & 25.69 & 40.86 & 2.30 \\
\hline \multicolumn{3}{|c|}{$\operatorname{Max}\left(\mathrm{kg} / \mathrm{m}^{2}\right)$} & 70.96 & 87.59 & 104.81 \\
\hline \multicolumn{3}{|c|}{ STDV } & 8.54 & 10.89 & 24.00 \\
\hline
\end{tabular}

with total reinforcement greater than required. The total required and provided reinforcement for the 31 villas were 724.8 tons and 1076.0 tons, respectively. The percentage of difference ranged from $2.3-104.8 \%$, with an average of $48.5 \%$ and a SD of 24.0.

\section{Discussion of the Results}

Table 2 shows the ratio of the reinforcement-tounit in the built-up floor area of each villa. Only two villas received less than $10 \%$ extra steel. This indicates that the reinforcement was underutilized but the cost and dead load were increased. At the same time, the bond between concrete and reinforcement may have been reduced due to insufficient space between bars. Table 3 shows that the largest percentage of extra reinforcement was used in the slabs followed by the footings, and the lowest percentage was found in the columns. Adding $75.6 \%$ extra reinforcement in the slabs aggravated the problem, as slabs naturally receive the largest amount of reinforcement. On the other hand, some columns were under-designed, which should be a concern because columns are critical for structural integrity and the possibility of failure should be remote. In fact, overdesign in columns should be considered acceptable for 
structural reasons (Zhao et al. 2004). Additionally, columns receive a relatively low amount of reinforcement and concrete, resulting in only a negligible cost increase. It is clear that, in most cases, municipality approval almost guarantees the safety of structures under working load conditions, but the economy of the construction receives insufficient attention. The high SD for the extra reinforcement provided for individual elements indicates obvious variability in the design methods and codes used [Table 3].

Table 3. Percentages of extra reinforcement in different members.

\begin{tabular}{lcccc}
\hline & Slabs & Beams & Columns & Footings \\
\hline $\begin{array}{l}\text { Average } \\
\text { of \% dif. }\end{array}$ & 75.63 & 44.17 & 37.42 & 57.61 \\
$\begin{array}{l}\text { Standard } \\
\text { deviation } \\
\% \text { dif. }\end{array}$ & 42.84 & 31.96 & 24.03 & 45.06 \\
$\begin{array}{l}\text { Max. } \\
\begin{array}{l}\text { Value of } \\
\% \text { dif. }\end{array}\end{array}$ & 162.04 & 102.91 & 78.28 & 182.35 \\
$\begin{array}{l}\text { Min. } \\
\text { Value of }\end{array}$ & & & & \\
$\%$ dif. & -2.83 & 0 & -13.26 & 0 \\
\hline
\end{tabular}

\section{Field Survey Results}

The results from the above study led to a field survey using a questionnaire prepared by the authors to explore causes of overdesigning and suggest solutions. The first part of the questionnaire covered general information about the respondents' educational backgrounds, experience with design code of practice, and the software used in design. The second and third parts explored the possible causes of overdesign and suggested solutions, respectively.

The causes and solutions associated with the issue of overdesign were suggested by the authors based on face-to-face discussions with 15 consulting and governmental engineers in the field of design and construction of villas in Oman. The respondents were asked to rank the priority of each reason or solution using a five-point Likert scale ranging from strongly disagree to strongly agree. First, a pilot study was conducted with five elements of each group. Accordingly, the questions were modified to eliminate possibly confusing wording, dual definitions, or ambiguities prior to the actual study presented here.
Responses from 56 engineers in consulting offices and 24 municipality engineers were analyzed. The selected participants from the consultants and municipalities had a minimum of a BSc degree in civil engineering with at least three years of field experience. To maximize the spread of the distribution, the selection criteria allowed the participation of only one member from each consulting office and at most two engineers from each municipality office.

The respondents from the consulting offices had a wide range of experience ( $\geq 5$ years) in the design of villas and multi-story buildings, and educational degrees from different countries. The majority of them adopted the British code BS8110 $(\div 1997)$ and/or the American code ACI318:08 (2008) in their designs and used structural analysis software, especially STAAD.Pro and/or SAP. Respondents from the municipalities had varying experiences $(\geq 3$ years $)$ in studying design drawings of villas and multi-story buildings. The majority of them did not use any structural analysis program and relied on knowledge gained from experience in the municipality offices and training courses offered by their employers. The questionnaire was issued to and collected from the respondents by hand, with a face-to-face meeting to explain the questions, if required.

Microsoft Excel software (Microsoft, Inc., Redmond. Washington, USA) was used to analyze the resulting data and produce descriptive statistics. Tables 4 and 5 show the relative importance of causes of overdesign based on consulting offices' and municipalities' respondents' opinions, respectively. The consultants emphasized the "need for a design review agent" as a top priority to ensure adequacy of design submitted by the consultants for approval. The other three most important reasons (reasons 2-4 in Table 4) are related to professional licensing and the qualifications of designers who are allowed to practice structural design. It is interesting to note that these reasons were sequentially followed by "fear of structural failure" (reason 5 of Table 4). This is possibly due to mistrust of workmanship at construction sites. The shortage of engineers in the municipality was a relatively important reason (reason 6 of Table 4) for overdesign in Omani villas. The majority of respondents from the municipalities were aware of possible structural overdesign in villas which the respondents justified with the statement "minor cost implication" (reason 1 in Table 5). The third most important reason indicated for villa overdesign was weak site supervision. 
Table 4. Relative importance (RI) of reasons of overdesign based on respondents from consulting engineers.

\begin{tabular}{|c|c|c|}
\hline No. & Priority of Causes by Consultants & RI \\
\hline 1. & $\begin{array}{l}\text { There is no authorized agent that is specialized in reviewing the consultant } \\
\text { structural design }\end{array}$ & 0.704 \\
\hline 2. & $\begin{array}{l}\text { Non-availability of engineering licensing for engineers in Oman to maintain the } \\
\text { quality of consultancy services. }\end{array}$ & 0.669 \\
\hline 3. & Engineers who gain good experience leave design offices for better paying jobs & 0.665 \\
\hline 4. & The local universities do not offer enough structural design courses & 0.658 \\
\hline 5. & Fear of structural failure & 0.654 \\
\hline 6. & The Engineers in municipality are few and can't review each step of the design & 0.638 \\
\hline 7. & $\begin{array}{l}\text { The owners believe that more steel lead to safer building which influences the } \\
\text { designer to increase the amount of steel }\end{array}$ & 0.635 \\
\hline 8. & Poor communications between consultant and municipality & 0.631 \\
\hline 9. & Municipality's engineers ask for more steel than the codes require. & 0.627 \\
\hline 10 & $\begin{array}{l}\text { The engineers in municipality are not willing to take risk when it comes to reduce } \\
\text { the amount of steel suggested by the designer. Even if they know that the mount of } \\
\text { steel is much more than what actually required. }\end{array}$ & 0.627 \\
\hline 11. & $\begin{array}{l}\text { Municipality's engineers do not have enough experience in visualizing the cost } \\
\text { implication of overdesigned structures }\end{array}$ & 0.619 \\
\hline 12. & $\begin{array}{l}\text { The duration that it takes to get approval from the municipality is one of the } \\
\text { common reasons behind the practice of possible over design as the consultants } \\
\text { tend to increase the amount of steel to easily gain approval of the municipality }\end{array}$ & 0.588 \\
\hline 13. & Design error & 0.588 \\
\hline 14. & $\begin{array}{l}\text { The owner's scope requirements during the design stage are unclear or not well } \\
\text { defined }\end{array}$ & 0.585 \\
\hline 15. & $\begin{array}{l}\text { Most of the consultants do not have collective experience about constructions in } \\
\text { Oman }\end{array}$ & 0.581 \\
\hline 16. & Some civil engineers are not specialized in structural design & 0.565 \\
\hline 17. & Diversity of codes' requirements for load and material factors of safety & 0.519 \\
\hline
\end{tabular}

Table 5. Relative importance (RI) of reasons of overdesign based on respondents from municipalities'

\begin{tabular}{|c|c|c|}
\hline No. & Priority of Causes Municipality & RI \\
\hline 1. & $\begin{array}{l}\text { Allow overdesign because the cost impact of overdesign is very minor compared to } \\
\text { the overall cost of the building }\end{array}$ & 0.8 \\
\hline 2. & $\begin{array}{l}\text { Engineers at the municipality are comparing the amount of steel provided in the } \\
\text { drawings with the recommendation of the maximum and the minimum steel from } \\
\text { the BS or ACI codes without carrying out any calculation }\end{array}$ & 0.765 \\
\hline 3. & $\begin{array}{l}\text { Minor over designing has its advantage to overcome problems of insufficient } \\
\text { supervision by consultants }\end{array}$ & 0.739 \\
\hline 4. & $\begin{array}{l}\text { The overall contractor's poor skills in the country have influence on the overdesign } \\
\text { phenomena. As the designer tend to increase the amount of steel to offset any } \\
\text { shortcoming of contractor }\end{array}$ & 0.652 \\
\hline 5. & $\begin{array}{l}\text { The grouping process of the structural elements is not accurate as the elements with } \\
\text { less required steel are grouped with elements with highly required steel and that is } \\
\text { to save some time in designing. }\end{array}$ & 0.643 \\
\hline 6. & $\begin{array}{l}\text { Engineers at the municipality are checking the structural design based on their } \\
\text { experience with similar structures and not based on formal code procedures }\end{array}$ & 0.6 \\
\hline
\end{tabular}

As far as the fourth ranked reason is concerned, the municipality engineers justified overdesign by blaming contractors' poor workmanship. For the last item, the engineers admit that they have no formal code procedure for checking designs. Tables 6 and 7 show the relative importance of solutions suggested by the authors as ranked by the consultants and the municipality respondents, respectively. The consultants assumed that the 
Table 6. Relative importance (RI) of suggested remedies based on respondents from consulting offices.

\begin{tabular}{llc}
\hline No. & \multicolumn{1}{c}{ Priority of Remedies by Consultants } & RI \\
\hline 1. & $\begin{array}{l}\text { A special agent shall be formed and authorized to approve structural } \\
\text { designs consisting of highly experienced, qualified engineers (BSc, MSc, }\end{array}$ & 0.781 \\
$\begin{array}{l}\text { PhD) other than municipality. } \\
\text { The structural design of any structure should be checked and approved by } \\
\text { a specialized engineer authorised by a special agent }\end{array}$ & 0.777 \\
3. $\quad \begin{array}{l}\text { No civil engineer shall be allowed to practice structural design without a } \\
\text { professional license }\end{array}$ & 0.777 \\
4. $\begin{array}{l}\text { A specialized structural engineer should be assigned to each large } \\
\text { construction project }\end{array}$ & 0.750 \\
5. $\quad \begin{array}{l}\text { A common learning database system should be shared among all } \\
\text { consultancy offices and municipality }\end{array}$ & 0.746 \\
6. $\quad \begin{array}{l}\text { A standard procedure should be established for all stages of project } \\
\text { starting from design to completion and handover. }\end{array}$ & 0.727 \\
7. $\begin{array}{l}\text { Municipality should force all consultancies to use unified code of practice } \\
\text { for structural design. }\end{array}$ & 0.608 \\
\hline
\end{tabular}

Table 7. Relative importance (RI) of suggested remedies based on respondents from Muscat municipality.

\begin{tabular}{|c|c|c|}
\hline No. & Priority of Remedies by Municipality & RI \\
\hline 1. & $\begin{array}{l}\text { No civil engineer shall be allowed to practice structural design } \\
\text { without having a professional license }\end{array}$ & 0.896 \\
\hline 2. & $\begin{array}{l}\text { A specialized structural engineer should be assigned to design } \\
\text { large projects }\end{array}$ & 0.896 \\
\hline 3. & $\begin{array}{l}\text { A special agent shall be formed to approve structural designs } \\
\text { consisting of highly experienced, qualified engineers (BSc, MSc, } \\
\text { PhD) other than municipality. }\end{array}$ & 0.852 \\
\hline 4. & $\begin{array}{l}\text { A standard procedure should be established for all stages of } \\
\text { project starting from design to completion and handover. }\end{array}$ & 0.85 \\
\hline 5. & $\begin{array}{l}\text { A common learning database system should be shared among all } \\
\text { consultancy offices and municipality }\end{array}$ & 0.843 \\
\hline 6. & $\begin{array}{l}\text { The structural design of any structure should be checked and } \\
\text { approved by a specialized engineer }\end{array}$ & 0.835 \\
\hline 7. & $\begin{array}{l}\text { A national standard should be established to include all } \\
\text { construction regulations and permits required for construction } \\
\text { projects in Oman. }\end{array}$ & 0.817 \\
\hline 8. & $\begin{array}{l}\text { A technical committee should be established to regularly review } \\
\text { design procedures and manuals, and follow their implementation }\end{array}$ & 0.774 \\
\hline 9. & $\begin{array}{l}\text { Municipality should force all consultancies to use unified code of } \\
\text { practice for structural design. }\end{array}$ & 0.765 \\
\hline
\end{tabular}

most important solution for villa overdesign would be to "hire or recruit the services of an agent in-charge for reviewing structural design". Unlike the consultants, the municipality engineers gave equal priority to the importance of "attaining a professional license to perform structural design" and the "dedication of a specialized structural engineer to design large projects". The third most important solution in the consultants' ranking was in line with the first: a villa's design should be reviewed by a specialized engineer authorized by the agent. The municipality engineers ranked as second the solution that a "specialized structural engineer should be assigned to design large projects". The solution ranked fourth by the consultants was a legal and procedural issue to mandate that no design could be submitted to the municipality unless the designer is licensed by a supreme authority in Oman. The municipality engineers indicated their belief that "a special agency should be formed to approve structural designs consisting 
of highly experienced and qualified engineers other than municipality" would be the third most important solution. It is clear from the discussion of causes and solutions that the consultants and the municipality engineers had different opinions on the causes of overdesign; however, they shared almost identical opinions as to the solutions, albeit with different weights for each proposed solution.

\section{Concluding Remarks}

This study focused on the structural redesign of 31 villas in the Muscat area using the British code. The aim was to find the required reinforcement based on redesign work and to compare the results with the provided reinforcement in the approved drawings. Based on an analysis of the results, the following concluding remarks can be made:

- Most structural elements of almost all studied villas were structurally overdesigned, which was represented by the provided reinforcement being more than required by building codes. The extra reinforcement totaled $162 \%$ in the slabs, $103 \%$ in the beams, $78.3 \%$ in the columns, and $182.4 \%$ in the footings.

- The percentage of total extra reinforcement in the 31 villas ranged from $2.30-104.81 \%$, with an average of $48.50 \%$ and a standard deviation of 24.00

- A field survey of consultants and municipality engineers indicated that the most important reasons for overdesign in Oman are an absence of authorized agents who specialize in reviewing structural design and the lack of an engineering licensing system. Additionally, respondents indicated that engineers who gain good experience leave design offices for better paying jobs. In the same survey, respondents indicated the three most important solutions to overdesign in Omani villas. First, the respondents expressed their belief that a special agency of highly experienced and qualified, non-municipality affiliated engineers should be authorized to approve structural designs. Second, civil engineers should be banned from practicing structural design without a professional license. Third, a specialized structural engineer should be assigned to design large projects.

\section{Acknowledgment}

The authors are indebted to the Building Permit Department at Muscat Municipality for providing the drawings and statistical data used in this research. The cooperation of the staff concerned is gratefully acknowledged and appreciated. Assistance in data collection and structural design by Al-Mazrui K. M. and Al Kasbi F. A, Airoon S. M, Al Kharousi H. H. Al Mujaini A. A. and AlJabri W. Z., is highly appreciated.

\section{References}

Al-Negheimish AI, Shuraim AB and Al-Tayyar AS (2002), Structural design practice for residential buildings in Riyadh: An overview. The $6^{\text {th }}$ Saudi Engineering Conference, King Fahad University of Petroleum and Minerals, Dhahran 3: 47-62.

American Concrete Institute ACI318 (2008), Building code requirements for structural concrete and commentary. 318-08, 604 Farmington Hills, MI, USA.

Arafah A, Al-Zaid R, Al-Haddad M, Ahmed AE, Al Sulaimani G and Wafa F (1999), Basic studies towards the development of a RC building code in Saudi Arabia. The Arabian Science and Engineering 24(1): 3-18.

Loading for Buildings, Part 1 Code of practice for dead and imposed loads BS6399-1, (1996), British Standard Institution, London.

Ministry of Economy, Sultanate of Oman (2011), Statistical Year Book No. 39.

Muscat Municipality, Directorate General of Technical affairs (2011), report on building permits.

Sadek AW, Al-Fadala S and Al-Mutairi N (2006), Improving the design of residential buildings in Kuwait. Emirates Journal for Engineering Research 11(2): 59-65.

Spread Sheets for Structural Design to BS8110, (2012), Reinforced Concrete Council (RCC) British Cement Association. UK. Retrieved from http://www.structural-engineering.fsnet. co.uk/rcc.htm.

Structural Analysis and Design Software, STAAD.Pro (2007), Research Engineering International, Bentley Systems, Inc., Exton, Pennsylvania, USA.

Structural Use of Concrete-Part 1 (1997), Code of practice for design and construction. BS8110:97, British Standard Institution, London.

Zhao YG, Ono T and Yoshhara K (2004), An investigation on column overdesign factors avoiding weak story mechanisms of steel 
Overdesign of Villa Structures in Oman

structures. The $13^{\text {th }}$ World Conference on Earthquake Engineering. Vancouver, BC, Canada, August 1-6, Paper No. 3448. 